\title{
Red mold rice extract represses amyloid beta peptide-induced neurotoxicity via potent synergism of anti-inflammatory and antioxidative effect
}

\author{
Chun-Lin Lee $\cdot$ Jyh-Jye Wang $\cdot$ Tzu-Ming Pan
}

Received: 24 February 2008 /Revised: 27 March 2008 /Accepted: 29 March 2008 / Published online: 26 April 2008

(C) Springer-Verlag 2008

\begin{abstract}
Amyloid $\beta$-peptide $(A \beta)$, a risk of Alzheimer's disease (AD), causes cell death by inflammation and oxidative stress. Red mold rice (RMR) fermented by Monascus species is regarded as cholesterol-lowering functional food in virtue of the metabolite monacolin $\mathrm{K}$ identified as lovastatin. In addition, RMR is also demonstrated to express antioxidation because of multiple antioxidants. Therefore, this study focuses on the synergism of RMR against $A \beta$ neurotoxicity and compares the effect between lovastatin and RMR including monacolin $\mathrm{K}$ and other functional metabolites. In this study, RE 568, an ethanol extract of RMR produced by strain Monascus purpureus NTU 568, is used to protect $\mathrm{PC} 12$ cell against A $\beta 40$ neurotoxicity. All tests contain the treatments with lovastatin or RE 568 including equal monacolin $\mathrm{K}$ levels in order to compare the effect and investigate whether other metabolites of RE 568 provide potent assistance against $A \beta 40$ neurotoxicity. In the results, monacolin $\mathrm{K}$ represses A $\beta 40$ neurotoxicity via repressing small G-protein-mediated inflammation, and other metabolites of RE 568 also exhibit potent antioxidative ability against $\mathrm{A} \beta$-induced oxidative
\end{abstract}

C.-L. Lee

R\&D Division, Sunway Biotechnology Company Limited,

Taipei, Taiwan

\section{J.-J. Wang}

Department of Biotechnology, Tajen University,

Ping Tung, Taiwan

T.-M. Pan $(\bowtie)$

Institute of Microbiology and Biochemistry,

National Taiwan University,

1, Sec. 4, Roosevelt Road,

Taipei, Taiwan 10617

e-mail: tmpan@ntu.edu.tw stress. Importantly, stronger effects on repressing the A $\beta 40$ induced cell death, inflammation, and oxidative stress are performed by RE 568 than that by the equal levels of lovastatin, which results from a potent synergism made up of monacolin $\mathrm{K}$, antioxidants, and anti-inflammatory agents. The present study is the first report to demonstrate the potent synergistic protection of RMR against $A \beta 40$ neurotoxicity, which would cause RMR to be developed as potential and novel functional food for the prophylaxis of $\mathrm{AD}$ pathogenesis.

Keywords Alzheimer's disease - Amyloid - Monascus . Monacolin K · Anti-inflammatory · Antioxidative

\section{Introduction}

Monascus-fermented rice known as the red mold rice (RMR) or red yeast rice has been used as a food colorant and spice and developed as the popular commercial capsule including 0.5-1.0-g red mold rice powder in Asia and the US. In the current study, monacolin $\mathrm{K}$ identified as lovastatin can be produced by Monascus species under solid and submerged culture (Endo 1979). Monacolin K proven as a 3-hydroxy-3-methylglutaryl-coenzyme A (HMG-CoA) reductase inhibitor can effectively block de novo cholesterol biosynthesis (Endo 1979). Monascusfermented product was gradually applied as the hypolipidemic functional food because it includes high monacolin $\mathrm{K}$ concentration (Lee et al. 2006a). Besides monacolin K, Monascus-fermented product including many functional secondary metabolites has been gradually found in current studies such as azaphilone pigments (ex. monascin, ankaflavin, rubropunctatin, monascorburin, rubropunctamine, and monascorburamine) exhibiting anti-inflammation, $\gamma$ aminobutyric acid known as the neurotransmitter and hypo- 
tensive agent, and a group of antioxidants including dimerumic acid, tannin, phenol, and unsaturated fatty acids (Akihisa et al. 2005; Aniya et al. 2000; Lee et al. 2006b; Su et al. 2003). In addition, our previous studies proved that Monascus-purpureus-NTU-568-fermented red mold rice was able to perform functional protection involved in hypolipidemic effect, antioxidation, and anti-inflammation (Lee et al. 2006a, b, 2007).

Alzheimer's disease (AD) known as the most common type of senile dementia is a progressive neurodegenerative condition characterized as the senile plaque of amyloid $\beta$ peptide (A $\beta$ ) fibrils in brain (Lee et al. 2006d). In vivo oxidation and free radical would cause the formation of $A \beta$ fibrils, and further, $A \beta$-fibril-induced oxidative stress and inflammatory response would occur and result in the formation of more $A \beta$ fibrils. The risk factor $A \beta$ and high levels of nitric oxide (NO), reactive oxygen species (ROS), and free radicals would be accumulated repetitiously and lead to more serious AD pathogenesis (Esposito et al. 2006; Sastre et al. 2006).

Statins has been applied to reverse the $A \beta$-induced cytotoxin via the robust anti-inflammatory effect in microglia model (Cordle et al. 2005). The anti-inflammatory effects exhibited by statins are postulated to result from the blockade of isoprenoid intermediates in cholesterol prophylaxis of AD pathogenesis (Liao and Laufs 2005). Isoprenoid intermediates result in the activation of small G-protein, which is regarded as the essential action for inflammatory signaling cascades (Liao and Laufs 2005). In addition, epidemiological studies suggested that treatment with cholesterol-lowering drugs could reduce the risk of developing AD (Rockwood et al. 2002; Wolozin et al. 2000). Therefore, statins are potential drug for the prophylaxis of $\mathrm{AD}$ pathogenesis, but more and more researches are concerned that long-term and overdose treatment with statins cause many side effects such as myopathy, liver and renal function impairment, hypothyroidism, and diabetes mellitus (Iskra et al. 2005). However, RMR has been proven to include high monacolin $\mathrm{K}$ levels and successfully mediates cholesterol and isoprenoid biosynthesis pathway (Lee et al. 2006a). Importantly, RMR used as a functional food for the prophylaxis of cardiovascular disease has been regarded as a safe and healthful traditional food and popularly accepted in Asia.

Although lovastatin has been proven to attenuate $A \beta 40$ induced neurotoxicity, RMR is different to lovastatin because it includes other functional compounds. In addition to monacolin $\mathrm{K}$, multiple compounds including dimerumic acid, azaphilones, furanoisophthalides, tannin, phenol, sterol, and monounsaturated fatty acid have been reported to exhibit anti-inflammatory and antioxidative effects (Akihisa et al. 2005; Aniya et al. 2000; Su et al. 2003). In the prophylaxis of $\mathrm{AD}$ pathogenesis, both antioxidative and anti-inflammatory ability are regarded as the key factors against $A \beta 40$-induced neurotoxicity. Therefore, monacolin $\mathrm{K}$ and other functional compounds may provide potent antiinflammatory and antioxidative ability against $A \beta 40$ induced neurotoxicity. This study would further evaluate whether the synergism performs more potent effect against $A \beta 40$-induced neurotoxicity than lovastatin drug or not. If the supposition is tenable, RMR will deserve to be developed as potential and novel functional food for the prophylaxis of $\mathrm{AD}$ pathogenesis.

\section{Materials and methods}

\section{Materials}

The $\mathrm{PC} 12$ cell line was obtained from Bioresource Collection and Research Center (60048; BCRC, Hsinchu, Taiwan). Roswell Park Memorial Institute (RPMI) 1640 medium, fecal bovine serum, and horse serum were purchased from Gibco BRL (Grand Island, NY, USA) and the A $\beta$ 1-40 from Tocris Bioscience (Ellisville, MO, USA). $\mathrm{A} \beta \quad 1-40$ was aggregated at $37^{\circ} \mathrm{C}$ for 7 days in order to prepare fibrillar A $\beta 40$. 3-(4,5-Dimethylthiazol-2-yl)-2,5diphenyltetrazolium bromide (MTT), ethylene glycol-bis (2-aminoethylether)- $N, N, N^{\prime}, N^{\prime}$-tetraacetic acid (EGTA), ethylenediaminetetraacetic acid (EDTA), dimethyl sulfoxide (DMSO), 2,2-diphenyl-1-picrylhydrazyl (DPPH), geranylgeranyl pyrophosphate, Greiss reagent, nitro blue tetrazolium (NBT), superoxide dismutase (SOD), sodium dodecyl sulfate (SDS), ferricytochrome c, vitamin C, cholesterol, mevalonate, monoclonal inducible nitric oxide synthase (iNOS) antibody, and monoclonal $\beta$-actin antibody were purchased from Sigma (St. Louis, MO, USA). Enhanced chemiluminescence (ECL) substrate was purchased from Millipore Co. (Billerica, MA, USA).

Preparation of ethanol extract of red mold rice

The long-grain rice (Ipomoea batatas) was purchased from a local supermarket in Taiwan to be used for red mold metabolites production under solid-state cultivation. The strains (M. purpureus NTU 560, 563, 564, 568, and CA) were used to prepare the red mold rice according to our previous study ( $\mathrm{Su}$ et al. 2003). After fermentation, the crushed and dried red mold rice $(5 \mathrm{~g})$ was further extracted by $95 \%$ ethanol of $50 \mathrm{ml}$ at $37^{\circ} \mathrm{C}$ for $24 \mathrm{~h}$ and then dried under vacuum. The dried extract yield was $10 \%$ of red mold rice. The dried ethanol extract was resolved to a final concentration of $1 \mathrm{mg} / \mathrm{ml}$ by distilled water. RE 560, RE 563 , $\mathrm{RE} 564$, RE 568, or RE CA is prepared from the extract of the red mold rice of M. purpureus NTU 560, 563, 564,568 , and CA, respectively. 


\section{Determination of the monacolin $\mathrm{K}$ concentration}

Red mold rice $(1 \mathrm{~g})$ was extracted with $50 \mathrm{ml}$ ethanol at $37^{\circ} \mathrm{C}$ for $24 \mathrm{~h}$ and then evaporated to dryness under vacuum. Ethanol extract was resolved to a final concentration of $1 \mathrm{mg} / \mathrm{ml}$ by $95 \%$ ethanol. The filtrate was then filtered with $0.45-\mu \mathrm{m}$ pore size filter and analyzed by high-performance liquid chromatography (PU2089 plus, Jasco Co., Tokyo, Japan). Chromatographic separation was conducted on a $\mathrm{C}_{18}$ column $\left(25 \mathrm{~cm} \times 4.6 \mathrm{~mm}\right.$ i.d., $5 \mu \mathrm{m}$, Discovery ${ }^{\circledR}$, Bellefontia, PA, USA). Acetonitrile-water-trifluoroacetate (55:45:0.05, $\mathrm{vol} / \mathrm{vol} / \mathrm{vol}$ ) was used as the mobile phase. The eluent was pumped at a flow rate of $1.0 \mathrm{ml} / \mathrm{min}$. Monacolin $\mathrm{K}$ was detected by ultraviolet detector (UV2075 plus, Jasco Co.) set at $238 \mathrm{~nm}$ (Lee et al. 2006c).

\section{Cell culture}

Neuronally differentiated PC12 cells were maintained in RPMI 1640 medium, supplemented with 5\% fetal bovine serum, $10 \%$ inactive horse serum, $2 \mathrm{mM}$ glutamine, $50 \mathrm{U} / \mathrm{ml}$ penicillin, and $50 \mathrm{mg} / \mathrm{ml}$ streptomycin in a humified incubator aerated with $95 \%$ air and $5 \% \mathrm{CO}_{2}$ at $37^{\circ} \mathrm{C}$.

\section{Evaluation of the antioxidative ability}

The DPPH radical scavenging method proposed by Aniya et al.(1999) was modified as follows: The reaction mixture consisted of $1 \mathrm{ml}$ of $0.1 \mathrm{mM}$ DPPH in ethanol, $0.95 \mathrm{ml}$ of $0.05-\mathrm{M}$ Tris- $\mathrm{HCl}$ buffer ( $\mathrm{pH} 7.4), 1 \mathrm{ml}$ of ethanol, and $50 \mu$ of sample or deionized water (control). The absorbance of the mixture was measured at $517 \mathrm{~nm}$ exactly 30 min after adding the extract (Aniya et al. 1999). The reducing power was determined using the method proposed by Oyaizu (1986). Conjugate diene inhibition was determined using the method proposed by Lingnert et al. (1979).

\section{MTT assay for cell viability}

PC12 cell viability was measured using the MTT reduction assay. MTT is reduced by viable cells to form blue formazan crystals, and inhibition of this reaction is representative of cellular redox alterations that could lead to neurotoxicity (Pollack et al. 1995). PC12 cells $\left(3 \times 10^{6}\right.$ cells) were plated into 96-well plates in a total volume of $100 \mu \mathrm{l}$ of culture medium and then cultured for $24 \mathrm{~h}$ at $37^{\circ} \mathrm{C}, 5 \% \mathrm{CO}_{2}$. After the pretreatment period, culture medium were removed and changed to serum-free RPMI 1640 medium. Cells were stimulated with fibrillar $A \beta 40$, fibrillar $A \beta 40$ and mevalonate, fibrillar $A \beta 40$ and cholesterol, or fibrillar $A \beta 40$ and GGpp and then pretreated with lovastatin or RE (RE 568, RE 560, RE 563, RE 564, RE CA) for $48 \mathrm{~h}$. MTT was added to the culture medium to yield a final concentration of
$0.5 \mathrm{mg} / \mathrm{ml}$. This mixture was incubated for $2 \mathrm{~h}$ at $37^{\circ} \mathrm{C}, 5 \%$ $\mathrm{CO}_{2}$. After incubation, the cell medium was removed, and $100 \mu \mathrm{l}$ of DMSO was added to dissolve the formed formazan crystals at room temperature for $10 \mathrm{~min}$ in the dark. The absorbance at $570 \mathrm{~nm}$ was measured and used to calculate the cell viability.

\section{Cholesterol measurement}

PC12 cells $\left(3 \times 10^{6}\right.$ cells $)$ were plated into six-well plates in a total volume of $2 \mathrm{ml}$ of culture medium and then cultured with $95 \%$ air and $5 \% \mathrm{CO}_{2}$ at $37^{\circ} \mathrm{C}$ for $24 \mathrm{~h}$. After the pretreatment period, culture media were removed and changed to serum-free RPMI 1640 medium containing mevalonate or cholesterol, and then cells were treated with lovastatin or RE 568 for $48 \mathrm{~h}$. Cholesterol concentrations were determined using a cholesterol assay kit (Randox Laboratories Ltd., Antrim, UK). Briefly, cells were removed from medium and lysed with lysis buffer $(1 \%$ Triton X-100, $20 \mathrm{mM}$ Tris, $\mathrm{pH} 7.5,100 \mathrm{mM} \mathrm{NaCl}, 40 \mathrm{mM}$ $\mathrm{NaF}, 0.2 \%$ SDS, $0.5 \%$ deoxycholate, $1 \mathrm{mM}$ EDTA, $1 \mathrm{mM}$ EGTA, and $1 \mathrm{mM} \mathrm{Na}_{3} \mathrm{VO}_{4}$ ) at $4^{\circ} \mathrm{C}$ for $30 \mathrm{~min}$. After that, cell lysates were incubated with cholesterol esterase, cholesterol oxidase, horseradish peroxidase, 4-aminoantipyrine, and phenol red at $37^{\circ} \mathrm{C}$ for $10 \mathrm{~min}$. The amount of cholesterol was determined indirectly by measuring absorbance at $500 \mathrm{~nm}$. In addition, Bradford method was used to normalize the cholesterol levels for protein concentration.

\section{iNOS immunoblotting}

PC12 cells $\left(3 \times 10^{6}\right.$ cells $)$ were plated into six-well plates in a total volume of $2 \mathrm{ml}$ of $2 \%$ culture medium and then cultured with $95 \%$ air and $5 \% \mathrm{CO}_{2}$ at $37^{\circ} \mathrm{C}$ for $24 \mathrm{~h}$. After the pretreatment period, cells were stimulated with fibrillar $A \beta 40$, fibrillar $A \beta 40$ and mevalonate, fibrillar $A \beta 40$ and cholesterol, or fibrillar $A \beta 40$ and GGpp, and then pretreated with lovastatin or RE 568 for $24 \mathrm{~h}$. Cells were collected and lysed with lysis buffer. Lysates were sonicated for $10 \mathrm{~s}$ and cleared by centrifugation $\left(16,000 \times g, 15 \mathrm{~min}, 4^{\circ} \mathrm{C}\right)$. Protein concentration was determined by the Bradford method. The samples $(50 \mu \mathrm{g})$ were separated on $10 \%$ SDS-polyacrylamide gel electrophoresis gels and transferred to polyvinylidene fluoride membranes. After blocking in a gelatin-NET solution, blots were incubated with anti-iNOS antibodies $(1: 1,000)$ at room temperature for $1 \mathrm{~h}$. Then, bands were incubated with antimouse horseradish-peroxidase-conjugated secondary antibodies $(1: 200,000)$ at room temperature for $1 \mathrm{~h}$ and visualized by ECL substrate with UVP AutoChemi Image system (UVP Inc., Upland, CA, USA). Protein loading was evaluated by antiactin antibody $(1: 3,000)$. 
Band intensities were quantified using UVP LabWork 4.5 software (UVP Inc.).

NO assay

PC12 cells $\left(3 \times 10^{6}\right.$ cells $)$ were plated into six-well plates in a total volume of $2 \mathrm{ml}$ of culture medium and then cultured with $95 \%$ air and $5 \% \mathrm{CO}_{2}$ at $37^{\circ} \mathrm{C}$ for $24 \mathrm{~h}$. After the pretreatment period, cells were stimulated with fibrillar $A \beta 40$, fibrillar $A \beta 40$ and mevalonate, fibrillar $A \beta 40$ and cholesterol, or fibrillar $A \beta 40$ and GGpp and then pretreated with lovastatin or RE 568 for $24 \mathrm{~h}$. One hundred microliters of cell medium were collected and assayed for NO levels with the Griess reagent (Green et al. 1982). The release of NO was determined indirectly by measuring the absorbance at $540 \mathrm{~nm}$. Triplicate measurements were obtained for each sample. In addition, $100 \mu \mathrm{l}$ was used for an MTT assay to normalize the Griess values for cell viability and number.

\section{Reactive oxygen species assay}

PC12 cells $\left(3 \times 10^{6}\right.$ cells $)$ were plated into six-well plates in a total volume of $2 \mathrm{ml}$ of $2 \%$ culture medium and then cultured for $24 \mathrm{~h}$ at $37^{\circ} \mathrm{C}, 95 \%$ air and $5 \% \mathrm{CO}_{2}$. After the pretreatment period, culture media were removed and changed to serum-free RPMI 1640 medium including NBT (final concentration, $1 \mathrm{mg} / \mathrm{ml}$ ). Cells were stimulated with fibrillar $A \beta 40$, fibrillar $A \beta 40$ and mevalonate, fibrillar $\mathrm{A} \beta 40$ and cholesterol, or fibrillar $\mathrm{A} \beta 40$ and GGpp and then treated with lovastatin or RE 568 for $2 \mathrm{~h}$ at $37^{\circ} \mathrm{C}, 5 \% \mathrm{CO}_{2}$. Cells were collected and lysed using lysis buffer and brief sonication $(10 \mathrm{~s})$. Aliquots of the samples were added to 96-well plates, and NBT reduction was measured by absorbance at $550 \mathrm{~nm}$ in triplicate.

\section{Measurement of oxidative stress}

The amount of superoxide produced was determined by measuring SOD-inhibitable reduction of cytochrome c. Cell cultures grown in 96-well plates were exposed to each treatment or vehicle in $150 \mu \mathrm{l}$ of treatment medium. Fifty microliters of ferricytochrome $\mathrm{c}(160 \mathrm{mM})$ in treatment medium with and without $800 \mathrm{U} / \mathrm{ml}$ SOD was added. The cultures were incubated for $15 \mathrm{~min}$ at $37^{\circ} \mathrm{C}, 95 \%$ air and $5 \% \mathrm{CO}_{2}$. Afterwards, the absorbance at $550 \mathrm{~nm}$ was read with a microplate spectrophotometer. The catalase activity of cell lysate was determined as previously described (Beers and Sizer 1952). Cells were harvested and sonicated in 0.05 -M sodium phosphate buffer ( $\mathrm{pH}$ 7.4) containing $0.1 \%$ Triton $\mathrm{X}-100$, and the supernatant was used for the catalase assay. Catalase activity was monitored by disappearance of $10 \mathrm{mM} \mathrm{H} \mathrm{H}_{2} \mathrm{O}_{2}$ by measuring the changes in absorbance at $240 \mathrm{~nm}$ for $3 \mathrm{~min}$. SOD activity was measured using SOD assay kit (Ransod, Randox Laboratories Ltd., Antrim, UK).

Western blot quantification and statistical analysis

The density of iNOS Western blot bands was determined using a UVP AutoChemi Image system (UVP Inc.). Band densities were normalized for protein loading by comparison with actin band densities. Three experiments were pooled to create graphical representations. Data were expressed as means $\pm \mathrm{SE}(n=3)$ and evaluated for significant differences with one-way analysis of variance followed by Duncan's multiple-range test. Differences were considered significant at $p<0.05$.

\section{Results}

Comparison of the effect of RE and lovastatin on relieving $\mathrm{A} \beta$-induced cytotoxin

M. purpureus NTU 568 demonstrated as an excellent strain exhibiting high monacolin $\mathrm{K}$ production and antioxidation in previous study was chosen as a mediator against $A \beta$ induced cytotoxin in this study (Lee et al. 2006a, b, c, d). As shown in Fig. 1, comparing control (Fig. 1a) and $A \beta 40$ treated group (Fig. 1b), fibril $\mathrm{A} \beta 40$ treatment causes PC12 cell lysis, damage, even death as assessed by phase-contrast microscopy. However, the addition of RE 568 extracted from M.-purpureus-NTU-568-fermented RMR can protect PC12 cell against A $\beta 40$-induced damage (Fig. 1c). A similar result performed by cell viability assay is shown in Fig. 1d. RE 568 can significantly reverse the neurotoxicity of $\mathrm{A} \beta 40$ in the PC12 cell model. Ultrapure lovastatin is also expected to clearly exhibit a dose-dependent response for protecting PC12 cells against toxic $\mathrm{A} \beta 40$ environment. Importantly, even though monacolin K levels of RE 568 are the same to lovastatin levels, we find that RE 568 frequently provides higher rescue than lovastatin. According to the results, the cholesterol-lowering monacolin $\mathrm{K}$ may be concluded as one of the major components of RE for relieving the $A \beta$-induced cytotoxin, but a more robust effect performed by RE 568 is probably due to the synergism of monacolin $\mathrm{K}$ and the other metabolites.

In order to investigate whether monacolin $\mathrm{K}$ is the functional active ingredient of RE inhibiting $A \beta$-induced cytotoxin, RE from various Monascus strains including different monacolin $\mathrm{K}$ concentration should be evaluated in the viability test. The results were shown in Table 1; those $\mathrm{RE}$ with higher monacolin $\mathrm{K}$ concentration almost lead to higher cell viability. It deserves to be mentioned that RE 560 including lower monacolin $\mathrm{K}$ concentration has difficulty in rescuing the $\mathrm{PC} 12$ cells from the toxic $\mathrm{A} \beta 40$ 
Fig. 1 Effects of RE 568 and lovastatin on the $A \beta 40$-induced neurotoxicity in PC12 cells. A $\beta 40$-induced cell death were evaluated with microscopic analysis $(\mathbf{a}-\mathbf{c})$ and MTT assay (d). PC12 cells $\left(3 \times 10^{6}\right)$ were treated with increasing concentration of RE 568 or lovastatin in the serum-free medium $(100 \mu \mathrm{l})$ containing $1.2 \mu \mathrm{M}$ A 340 fibrils for $48 \mathrm{~h}$. Microscopic analysis and MTT assay were carried out after treatment. The damaged and dead cells are presented as the arrowed cells in the graph. The data are the means $\pm \mathrm{SE}$ expressed as percentage of control values $(n=3)$. Statistical comparison was made using ANOVA, followed by Duncan's test. ${ }^{*} p<0.05$

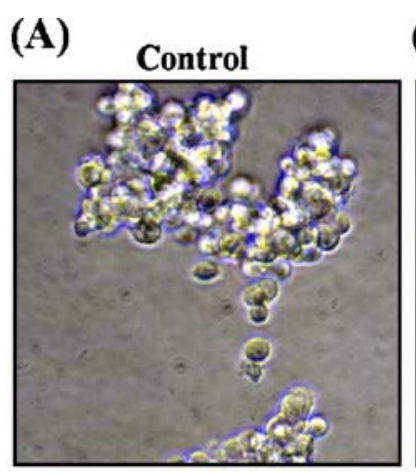

(B) Fibrils A 440

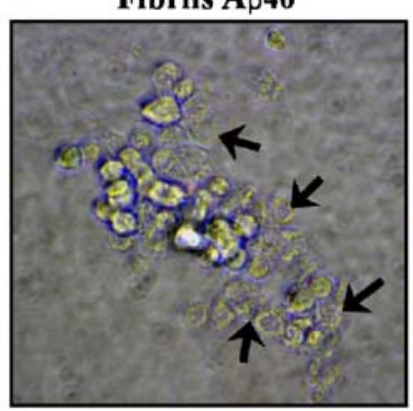

(C) Fibrils AB40+ RE 568

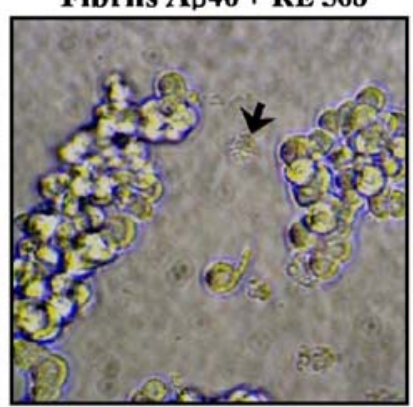

(D)

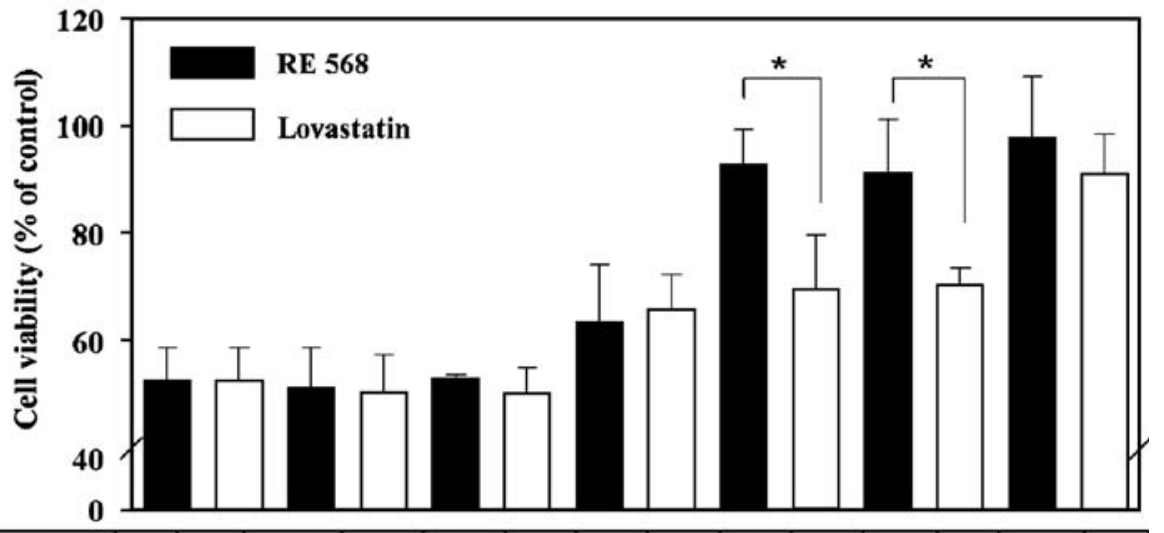

\begin{tabular}{|c|c|c|c|c|c|c|c|c|c|c|c|c|c|c|}
\hline $\begin{array}{l}\text { RE } 568(\mathrm{ng} / \mathrm{ml}) \\
\text { Monacolin K } \\
(\mathrm{ng} / \mathrm{ml})\end{array}$ & - & - & $\begin{array}{c}0.2 \\
0.0019\end{array}$ & - & $\begin{array}{c}2.0 \\
0.019\end{array}$ & - & $\begin{array}{c}20 \\
0.19\end{array}$ & - & $\begin{array}{c}200 \\
1.9\end{array}$ & - & $\begin{array}{c}2000 \\
19\end{array}$ & - & $\begin{array}{c}20000 \\
190\end{array}$ & - \\
\hline Lovastatin $(\mathrm{ng} / \mathrm{ml})$ & - & - & - & 0.002 & - & 0.02 & - & 0.2 & - & 2.0 & - & 20 & - & 200 \\
\hline
\end{tabular}

environment. Therefore, monacolin $\mathrm{K}$ can be regarded as the functional active ingredient of $R E$ inhibiting $A \beta$ induced cytotoxin. However, it is not absolute relationship between monacolin $\mathrm{K}$ concentration and neuroprotection because monacolin $\mathrm{K}$ should not be the only functional active ingredient according to the result of Table 1. RE 568 containing $47.5 \mathrm{ng} / \mathrm{ml}$ monacolin $\mathrm{K}$ would gain higher cell viability at $98 \%$ than $50 \mathrm{ng} / \mathrm{ml}$ lovastatin at $83 \%$. In addition, both RE 564 and RE CA $(5,000 \mathrm{ng} / \mathrm{ml})$ including lower monacolin $\mathrm{K}$ levels at $30.1 \mathrm{ng} / \mathrm{ml}$ and $29.1 \mathrm{ng} / \mathrm{ml}$ would gain higher cell viability than RE 568. These results certainly evidence that although monacolin $\mathrm{K}$ can be regarded as the major functional active ingredient, the other metabolites may potently assist monacolin $\mathrm{K}$ in rescuing cell viability from toxic fibrils $\mathrm{A} \beta 40$.

RE 568 represses $A \beta$ neurotoxicity via blockading isoprenoid pathway

As proven by previous studies, $A \beta$ neurotoxicity for microglia or neuron is sensitively modulated by cholesterol and isoprenoid pathway (Cordle et al. 2005). As shown in the above-mentioned results, monacolin $\mathrm{K}$ is an important compound of RE to protect $\mathrm{PC} 12$ cell against the $\mathrm{A} \beta$ induced cytotoxin. Monacolin $\mathrm{K}$ known as a HMG-CoA
Table 1 The effect of lovastatin or RE from various Monascus strains protecting $\mathrm{PC} 12$ cells viability against $\mathrm{A} \beta 40$-induced cytotoxin

\begin{tabular}{llrr}
\hline Sample & $\begin{array}{l}\text { Monacolin K } \\
\text { concentration } \\
(\mathrm{ng} / \mathrm{ml} \text { medium })\end{array}$ & $\begin{array}{l}\text { Sample } \\
\text { concentration } \\
(\mathrm{ng} / \mathrm{ml} \text { medium })\end{array}$ & \multicolumn{1}{l}{$\begin{array}{l}\text { Cell } \\
\text { viability (\%) }\end{array}$} \\
\hline Control & - & 0 & $62 \pm 18.3$ \\
Lovastatin & 50 & 50 & $83 \pm 13.4$ \\
Lovastatin & 500 & 500 & $106 \pm 14.7$ \\
RE 568 & 4.75 & 500 & $85 \pm 11.5$ \\
RE 568 & 47.5 & 5,000 & $98 \pm 26.7$ \\
RE 560 & - & 50 & $65 \pm 1.63$ \\
RE 560 & - & 500 & $69 \pm 2.90$ \\
RE 560 & - & 5,000 & $68 \pm 1.09$ \\
RE 563 & 0.216 & 50 & $66 \pm 12.6$ \\
RE 563 & 2.165 & 500 & $80 \pm 9.25$ \\
RE 563 & 21.7 & 5,000 & $95 \pm 8.41$ \\
RE 564 & 0.301 & 50 & $92 \pm 18.2$ \\
RE 564 & 3.007 & 500 & $120 \pm 20.3$ \\
RE 564 & 30.1 & 5,000 & $124 \pm 7.80$ \\
RE CA & 0.291 & 50 & $100 \pm 6.80$ \\
RE CA & 2.905 & 500 & $114 \pm 10.0$ \\
RE CA & 29.1 & 5,000 & $137 \pm 37.1$ \\
\hline
\end{tabular}




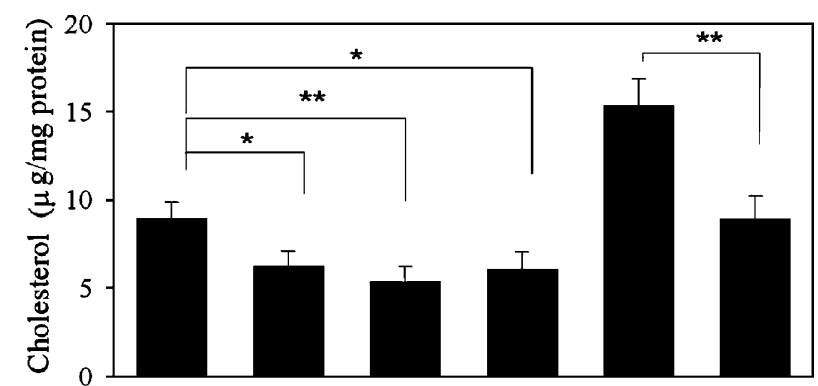

\begin{tabular}{|l|c|c|c|c|c|c|}
\hline Mevalonate $(\mathrm{mM})$ & - & - & - & - & 5.0 & 5.0 \\
\hline Lovastatin $(\mathrm{\mu g} / \mathrm{ml})$ & - & - & - & 1.0 & - & - \\
\hline RE 568 $(\mu \mathrm{g} / \mathrm{ml})$ & - & 10 & 50 & - & - & 10 \\
Monacolin K $(\mathrm{\mu g} / \mathrm{ml})$ & - & 0.095 & 0.475 & - & - & 0.095 \\
\hline
\end{tabular}

Fig. 2 Cholesterol-lowering effect of RE 568 and lovastatin in PC12 cells. Cholesterol levels of PC12 cells $\left(3 \times 10^{6}\right)$ raised with or without $5 \mathrm{mM}$ mevalonate were treated by RE 568 or lovastatin for $48 \mathrm{~h}$. After treatment, cholesterol levels were measured by cholesterol assay kit and normalized by total protein concentration. The data are the means \pm SE expressed as percentage of control values $(n=3)$. Statistical comparison was made using ANOVA, followed by Duncan's test. ${ }^{*} p<$ $0.05 ; * * p<0.01$

reductase inhibitor would blockade the biosynthesis pathway of cholesterol and isoprenoids (Endo 1979). Therefore, cholesterol-lowering effect can be regarded as an ability of RE blockading isoprenoid pathway. Figure 2 clearly expresses a significant downregulation of cholesterol levels by RE 568 supplementation in PC12 cells. Even though statins have been proven to repress $A \beta$-induced cytotoxin via the blockade of mevalonate biosynthesis (Cordle and Landreth 2005), the mechanism of repressing $A \beta$ neurotoxicity with RE comprising complex substances cannot be directly imitated by that of ultrapure lovastatin. To investigate whether RE can provide more potent protection against mevalonate-raised $A \beta$ neurotoxicity than lovastatin or not is important. The results were shown in Fig. 3. Mevalonate supplementation would strengthen the $A \beta$ induced neurotoxicity, but cholesterol supplementation would not (Fig. 3a,b). This result indicates that the isoprenoid pathway is the key pathway for increasing $A \beta$ induced neurotoxicity. Lovastatin is expected to repress the raised $A \beta$ neurotoxicity, but the protective ability is sensitive to be reversed and become slight by the mevalonate supplementation. Importantly, the defect would not occur by RE 568 treatment. A significant difference between the inhibitory effect of mevalonate-raised $A \beta$ neurotoxicity by RE 568 and that by lovastatin is clearly shown in Fig. 3b. RE 568 can protect PC12 cell against $2.5 \mathrm{mM}$ mevalonate-raised $\mathrm{A} \beta$ neurotoxicity and significantly rescue the cell viability from $29 \%$ to $68 \%$, but the rescue by lovastatin would be completely reversed by mevalonate supplementation.

Isoprenoid GGpp is an important factor to mediate the activity of small G-protein involved in $\mathrm{A} \beta$-induced inflam- matory response. Therefore, GGpp is used to substitute for mevalonate, so as to directly activate small G-protein. As shown in Fig. 3c, GGpp directly acts as a more robust stimulator in $A \beta$-induced cytotoxin, which is difficult to be rescued by RE 568 or lovastatin. This result certainly demonstrates that monacolin $\mathrm{K}$ of RE 568 protects $\mathrm{PC} 12$ cell against $A \beta$ neurotoxicity via blockade of isoprenoids biosynthesis. Inflammatory response and oxidative stress are both regarded as the key and serious damage for the reason of $A \beta$-induced cytotoxin. The mechanism of statins against $A \beta$-induced cytotoxin is due to the inactivation of isoprenoid-mediated small G-protein and indirectly attenuated formation of proinflammatory cytokine such as interleukin-1 $\beta$ (IL-1 $\beta$ ), tumor necrosis factor, and IL-6 (Cordle and Landreth 2005). Therefore, anti-inflammation and antioxidation should be the most important ability against $A \beta$ neurotoxicity. $R E$ was repeatedly proven to perform more potent protection against $A \beta$ neurotoxicity than lovastatin in this study. We suppose other substances of RE must provide some potent abilities against $A \beta$ neurotoxicity in addition to monacolin $\mathrm{K}$. Because of this doubtful point, RE and lovastatin should be evaluated for their protective ability against $A \beta$-induced inflammation and oxidative stress, respectively.

The effect of RE repressing $A \beta$-induced inflammatory response

Many researches indicated that $A \beta$ would cause neuron, microglia, and astrocytes to release inflammatory factors including iNOS with the subsequent production of NO (Cordle and Landreth 2005). In this study, RE 568 is used to test the effect of repressing $A \beta 40$-induced iNOS expression. As shown in the result of immunoblotting (Fig. 4a), iNOS expression of PC12 cell can be strongly stimulated by $A \beta 40$, and RE 568 exhibits a dose-dependent ability to downregulate the $A \beta$-induced iNOS expression. According to the results of Fig. 3 and above foregoing supposition, monacolin $\mathrm{K}$ of RE 568 act as a mediator of isoprenoids pathway to rescue $\mathrm{PC} 12$ cells viability in $\mathrm{A} \beta 40$ environment, which may result from the anti-inflammation mechanism as statins. However, more potent protection against $A \beta$ neurotoxicity performed by RE probably results from more potent anti-inflammatory ability performed by the synergism of monacolin $\mathrm{K}$ and other metabolites. This suspicion can be solved in Figs. 4 and 5. Figure $4 \mathrm{~b}$ indicates $\mathrm{NO}$ production of $\mathrm{PC} 12$ cells would be increased by twofold under $A \beta 40$-rich environment, but that can be significantly reversed after RE 568 treatment. However, only a slight anti-inflammatory effect is shown in lovastatin treatment. Figure $4 \mathrm{c}$ also indicates that lovastatin is unable to resist the $\mathrm{A} \beta$-induced $\mathrm{NO}$ production after mevalonate supplementation. Although mevalonate also reverses the 
Fig. 3 Effects of RE 568 and lovastatin on the isoprenoidstimulated A $\beta 40$ neurotoxicity in $\mathrm{PC} 12$ cells. $\mathrm{PC} 12$ cells $(3 \times$ $10^{6}$ ) were treated with or without RE 568 or lovastatin and exposed to $A \beta 40$ and cholesterol (a), or $\mathrm{A} \beta 40$ and mevalonate (b), or A $\beta 40$ and GGpp (c) for $48 \mathrm{~h}$. After treatment, MTT assay is used to measure the viability of $\mathrm{PC} 12$ cells. The data are the means $\pm \mathrm{SE}$ expressed as percentage of control values ( $n=$ 3). Statistical comparison was made using ANOVA, followed by Duncan's test. ${ }^{*} p<0.05$ and $* * p<0.01$ compared with control, ${ }^{*} p<0.05$ compared with $1.2 \mu \mathrm{M} \mathrm{A} \beta 40$ without mevalonate, ${ }^{*} p<0.05$ compared with $1.2 \mu \mathrm{M}$ A $\beta 40$ plus $0.5 \mathrm{mM}$ mevalonate, ${ }^{\dagger} p<0.05$ and ${ }^{\dagger} p<0.01$ compared with $1.2 \mu \mathrm{M}$ A $\beta 40$ plus $2.5 \mathrm{mM}$ mevalonate
(A)

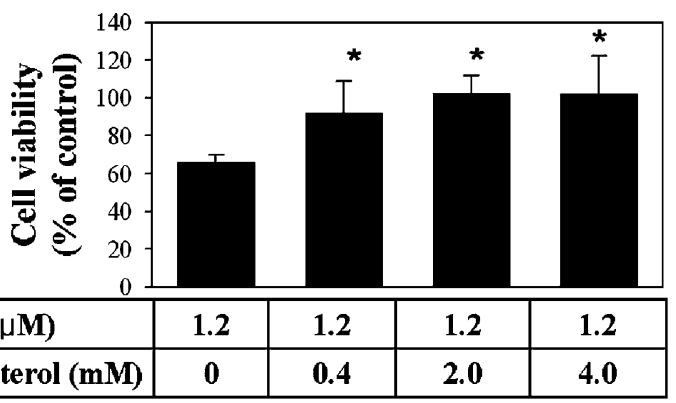

(B)

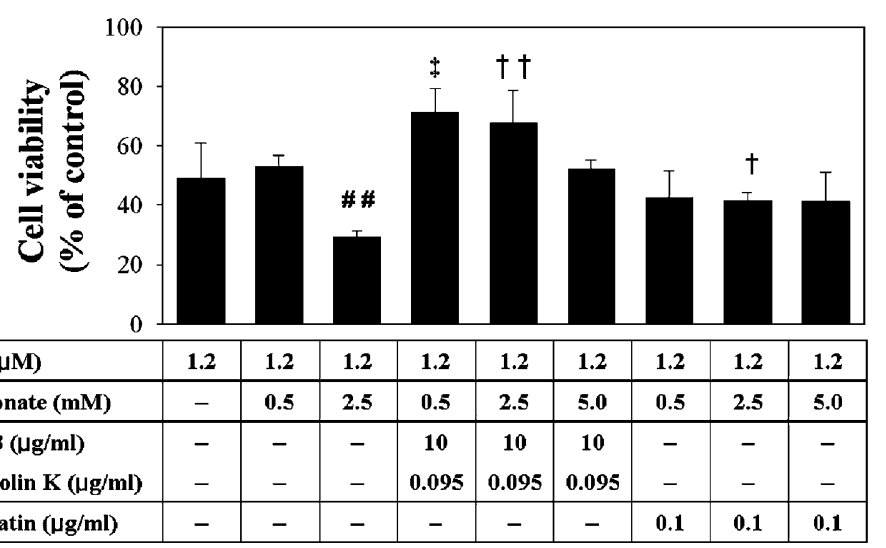

(C)

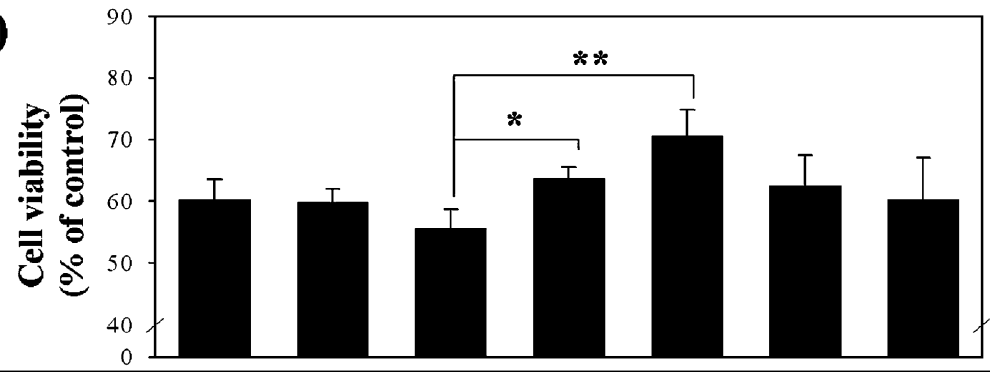

\begin{tabular}{|l|c|c|c|c|c|c|c|}
\hline Aß40 $(\mu \mathrm{M})$ & 1.2 & 1.2 & 1.2 & 1.2 & 1.2 & 1.2 & 1.2 \\
\hline GGpp $(\mathrm{mM})$ & & 0.5 & 1.0 & 1.0 & 1.0 & 1.0 & 1.0 \\
\hline RE 568 $(\mu \mathrm{g} / \mathrm{ml})$ & - & - & - & 10 & 100 & - & - \\
Monacolin K $(\mu \mathrm{g} / \mathrm{ml})$ & - & - & - & 0.095 & 0.95 & - & - \\
\hline Lovastatin $(\mu \mathrm{g} / \mathrm{ml})$ & - & - & - & - & - & 0.01 & 0.1 \\
\hline
\end{tabular}

effect of RE 568 repressing $\mathrm{A} \beta$-induced NO production, the reverse strength for RE 568 treatment is finite and less than that for treatment of equal lovastatin levels.

A $\beta 40$ treatment would also dramatically increase ROS levels, and a suppression of ROS generation was sensitive to RE 568 or lovastatin (Fig. 5a). Crucially, cell death and inflammatory factors are attenuated after RE 568 or lovastatin treatment. However, serious $A \beta$-induced inflammatory response occurred after stimulating isoprenoid biosynthesis. Figure $5 \mathrm{~b}$ indicates that RE 568 treatment can express dose-dependent response on reducing ROS generation even though mevalonate and $\mathrm{A} \beta 40$ were added for stimulating inflammatory response, but a significant inhibitory effect cannot be found in lovastatin treatment. A definite result points that RE 568 treatment $(25 \mu \mathrm{g} / \mathrm{ml})$ including monacolin $\mathrm{K}$ of $0.238 \mu \mathrm{g} / \mathrm{ml}$ can reveal better effect on repressing $A \beta 40$-induced inflammation as compared with lovastatin treatment $(0.25 \mu \mathrm{g} / \mathrm{ml})$.

In addition, increasing the GGpp levels would significantly enhance the generation of $A \beta 40$-induced ROS with a dose-dependent response (Fig. 5c). GGpp is certainly a potent precursor to enhance $A \beta 40$-induced inflammatory response. Neither RE 568 nor lovastatin can exhibit a significant effect to decrease the ROS generation stimulated by $A \beta 40$ and GGpp-activated small G-protein, but inhibiting ROS levels by lovastatin treatment still compares poorly with that by RE 568 treatment. The antioxidant and anti-inflammatory agent of RE 568 probably attenuate A 340 -induced ROS in addition to monacolin $\mathrm{K}$ having the same structure with lovastatin. 
Fig. 4 Effects of RE 568 and lovastatin on the inhibition of A 340 -induced iNOS expression and nitric oxide levels in PC12 cells. a iNOS was detected by immunoblotting in $\mathrm{A} \beta 40$-treated PC12 cells. Band densities were normalized for protein loading by comparison with actin band densities. b Effects of RE 568 or lovastatin on the inhibition of mevalonate stimulating $A \beta 40$ induced nitric oxide levels. c Effects of RE 568 or lovastatin on the inhibition of GGpp stimulating $A \beta 40$-induced nitric oxide levels. Nitric oxide levels were measured by Griess reagent and normalized by MTT assay. The data are the means \pm SE expressed as percentage of control values $(n=3)$. Statistical comparison was made using ANOVA, followed by Duncan's test. ${ }^{*} p<0.05$ and $* * p<0.01$ compared with control, ${ }^{\#} p<0.05,{ }^{\# \#} p<0.01$, and ${ }^{\# \# \#} p<$ 0.001 compared with $1.2 \mu \mathrm{M}$ $\mathrm{A} \beta 40,{ }^{\ddagger} p<0.05$ compared with $1.2 \mu \mathrm{M}$ A $\beta 40$ plus $0.5 \mathrm{mM}$ mevalonate, ${ }^{\dagger} p<0.05$ and ${ }^{\dagger \dagger} p<$ 0.05 compared with $1.2 \mu \mathrm{M}$ $\mathrm{A} \beta 40$ plus $2.5 \mathrm{mM}$ mevalonate
(A)
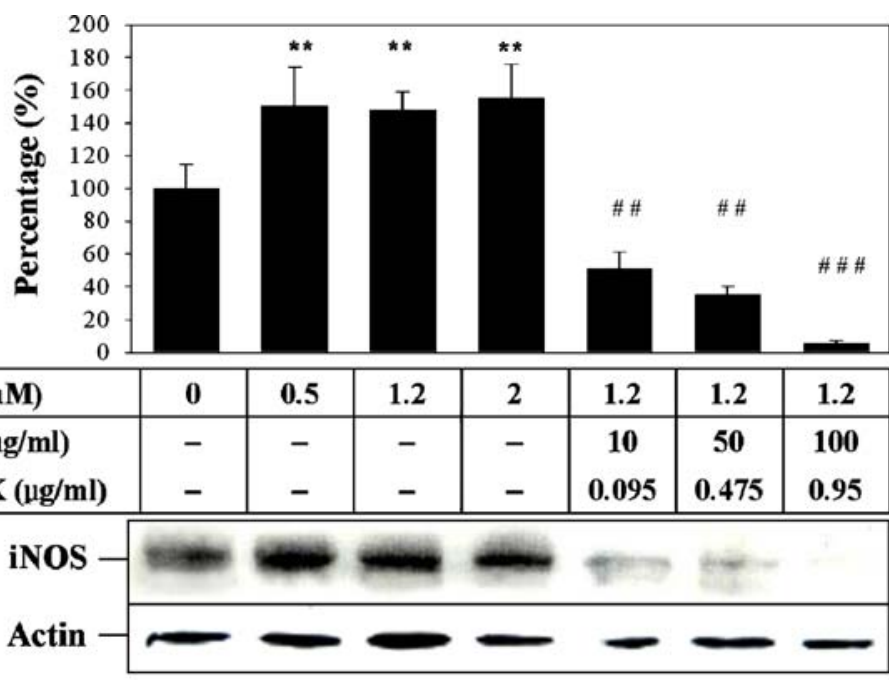

(B)

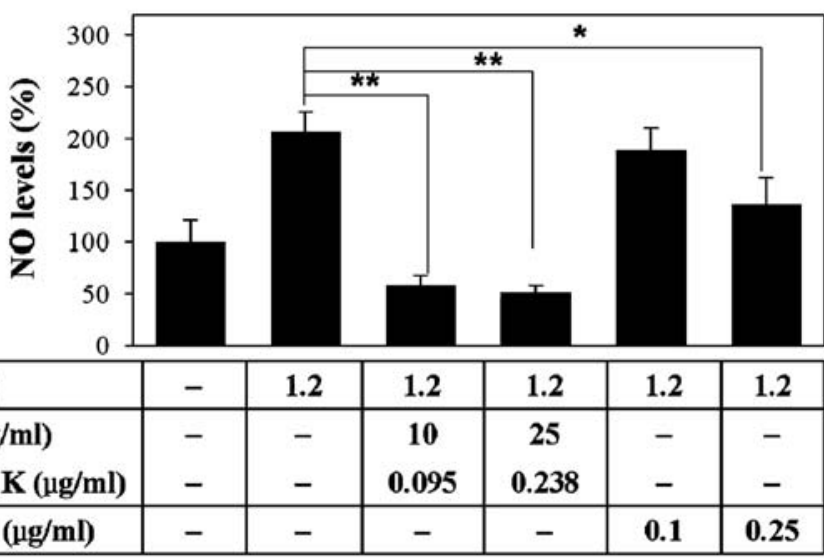

(C)

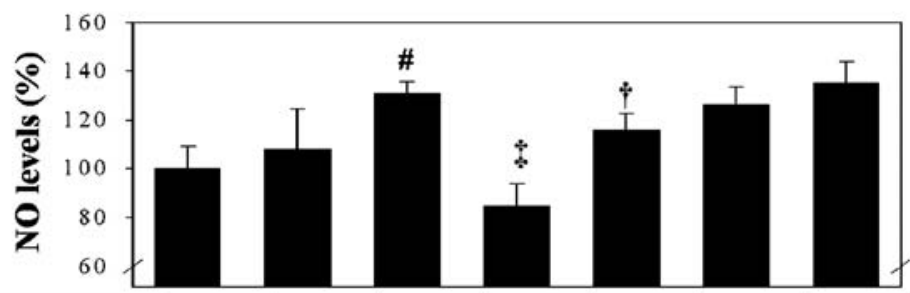

\begin{tabular}{|l|c|c|c|c|c|c|c|}
\hline A $\beta 40(\mu \mathrm{M})$ & 1.2 & 1.2 & 1.2 & 1.2 & 1.2 & 1.2 & 1.2 \\
\hline Mevalonate $(\mathrm{mM})$ & - & 0.5 & 2.5 & 0.5 & 2.5 & 0.5 & 2.5 \\
\hline RE 568 $(\mu \mathrm{g} / \mathrm{ml})$ & - & - & - & 10 & 10 & - & - \\
Monacolin K $(\mu \mathrm{g} / \mathrm{ml})$ & - & - & - & 0.095 & 0.095 & - & - \\
\hline Lovastatin $(\mu \mathrm{g} / \mathrm{ml})$ & - & - & - & - & - & 0.1 & 0.1 \\
\hline
\end{tabular}

RE 568 expresses excellent antioxidative ability and repression of $\mathrm{A} \beta$-induced oxidative stress

Although the RE 568 treatment and lovastatin treatment, respectively, include equal levels of monacolin $\mathrm{K}$ and lovastatin, more potent effect on repressing $A \beta$-induced inflammatory response was certainly found in RE 568 treatment than lovastatin treatment. In order to gain forceful evidence that $\mathrm{RE}$ performed more robust effect on repressing $A \beta$ neurotoxicity than lovastatin, antioxidative ability and repression of $A \beta$-induced oxidative stress by RE 568 and lovastatin should be evaluated. The antioxidative ability of RE 568 is evaluated by in vitro measurement including reducing power, DPPH radical scavenging activity, and conjugate diene inhibition. As shown in Fig. 6a, RE 568 $(100 \mu \mathrm{g} / \mathrm{ml})$ can exhibit antioxidative ability as strong as $200 \mu \mathrm{M}$ vitamin $\mathrm{C}$ but lovastatin drug shows weak and feeble effect on the antioxidative ability. The antioxidation is 
Fig. 5 Effects of RE 568 and lovastatin on the inhibition of A $\beta 40$-induced ROS levels in PC12 cells. PC12 cells $\left(3 \times 10^{6}\right)$ were treated with RE 568 or lovastatin in the serum-free medium containing $A \beta 40$ fibrils (a), or $\mathrm{A} \beta 40$ fibrils plus mevalonate (b), or $A \beta 40$ fibrils plus GGpp (c) for $2 \mathrm{~h}$. ROS levels were determined by NBT assay. The data are the means \pm SE expressed as percentage of control values $(n=3)$. Statistical comparison was made using ANOVA, followed by Duncan's test. ${ }^{*} p<0.05,{ }^{* *} p<0.01$, and $* * * p<0.001$
(A)

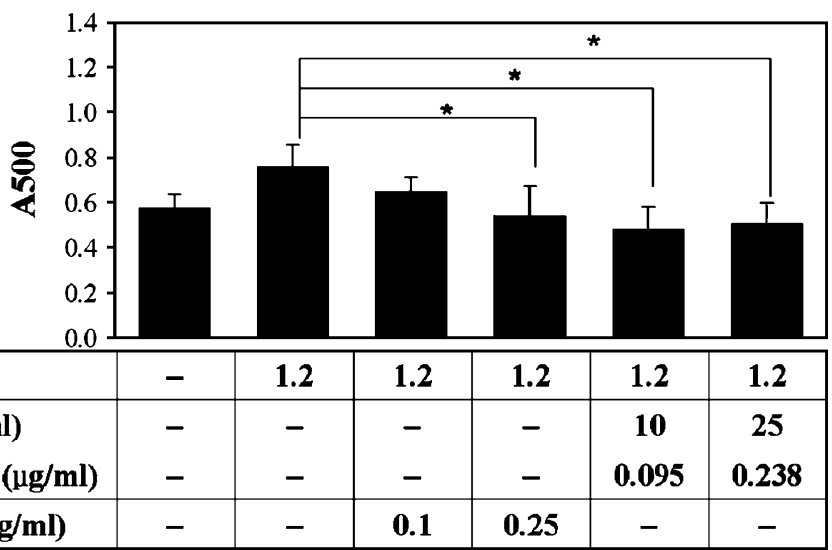

(B)

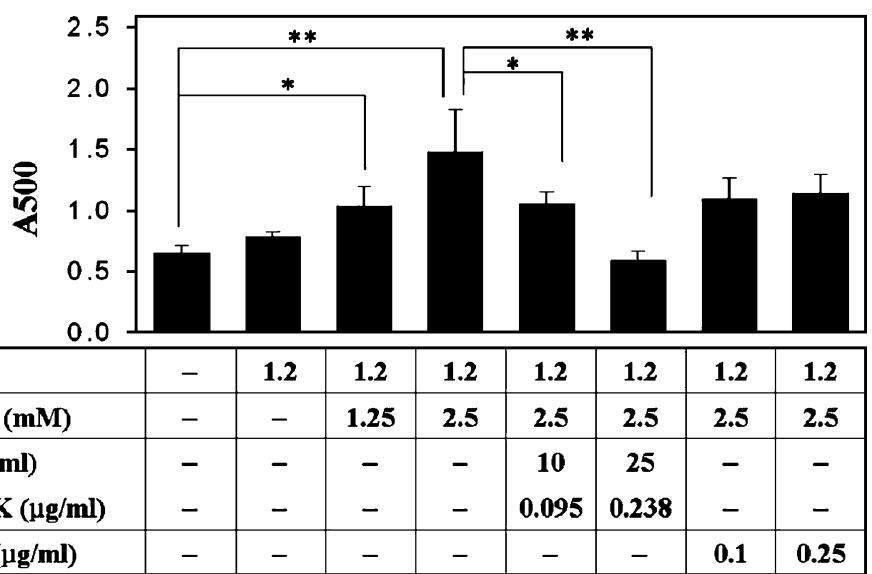

(C)

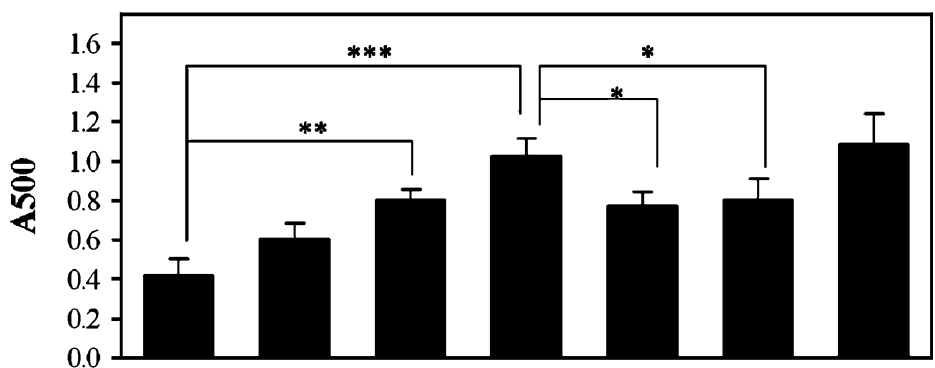

\begin{tabular}{|l|c|c|c|c|c|c|c|}
\hline Aß40 $(\mu M)$ & - & 1.2 & 1.2 & 1.2 & 1.2 & 1.2 & 1.2 \\
\hline GGpp $(\mathrm{mM})$ & - & - & 0.5 & 1.0 & 1.0 & 1.0 & 1.0 \\
\hline RE 568 $(\mu \mathrm{g} / \mathrm{ml})$ & - & - & - & - & 10 & 25 & - \\
Monacolin K $(\mu \mathrm{g} / \mathrm{ml})$ & - & - & - & - & 0.095 & 0.238 & - \\
\hline Lovastatin $((\mu \mathrm{g} / \mathrm{ml})$ & - & - & - & - & - & - & 0.25 \\
\hline
\end{tabular}

considered as a positive effect for repressing $A \beta$-induced oxidative stress. The results indicate the advantage of using $\mathrm{RE}$ to attenuate $\mathrm{A} \beta$ neurotoxicity, in which small G-protein inactivator monacolin $\mathrm{K}$ and other complex substances with good antioxidative ability are included in RE 568 and cause synergism against $\mathrm{A} \beta$ neurotoxicity.

The formation of superoxide or free radical is proven to occur as cell was damaged by $\mathrm{A} \beta$. Many studies also explained that $A \beta$ leading to cell damage is due to the occurrence of oxidative stress (Gao and Tang 2006; Iuvone et al. 2006). According to these reasons, to exhibit excellent antioxidation by RE 568 is desired to relieve cell damage from $A \beta$-induced oxidative stress. As shown in Fig. $6 \mathrm{~b}, \mathrm{RE}$ 568 treatment performs significant relief on $A \beta 40$-indued superoxide levels. In addition, we observed an increase in SOD activity after the exposure of cells to $A \beta$, which might be direct induction or a compensatory reaction against $A \beta$ induced oxidative damage (Xiao et al. 2000), and treatment with RE-568-attenuated $\mathrm{A} \beta$ caused an increase in SOD. Treatment with RE 568 also enhances catalase activity of 
Fig. 6 Effects of RE 568 or lovastatin on antioxidation and protection against $A \beta 40$ induced oxidative stress. a DPPH radical scavenging activity, conjugate diene inhibition, and reducing power were used as the markers of antioxidative ability of RE 568 $(100 \mu \mathrm{g} / \mathrm{ml})$ and lovastatin $(1 \mu \mathrm{g} / \mathrm{ml})$. Vitamin C $(200 \mu \mathrm{M})$ was used as the positive control. b Effects of RE 568 or lovastatin on the inhibition of A $\beta 40$-induced oxidative stress. PC12 cells were treated with RE 568 or lovastatin in the serumfree medium containing $1.2 \mu \mathrm{M} \mathrm{A} \beta 40$ fibrils for $24 \mathrm{~h}$. Superoxide levels, SOD activity, and catalase activity were chosen as the makers. The data are the means $\pm \mathrm{SE}$ expressed as percentage of control values $(n=$ 3). Statistical comparison was made using ANOVA, followed by Duncan's test. $* p<0.05$ and $* * p<0.01$
(A)

(B)

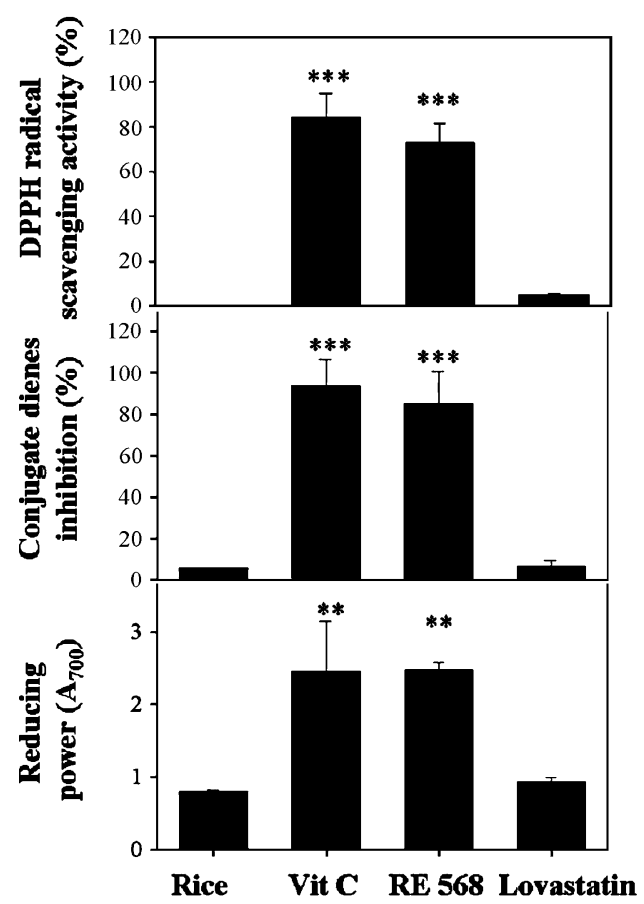

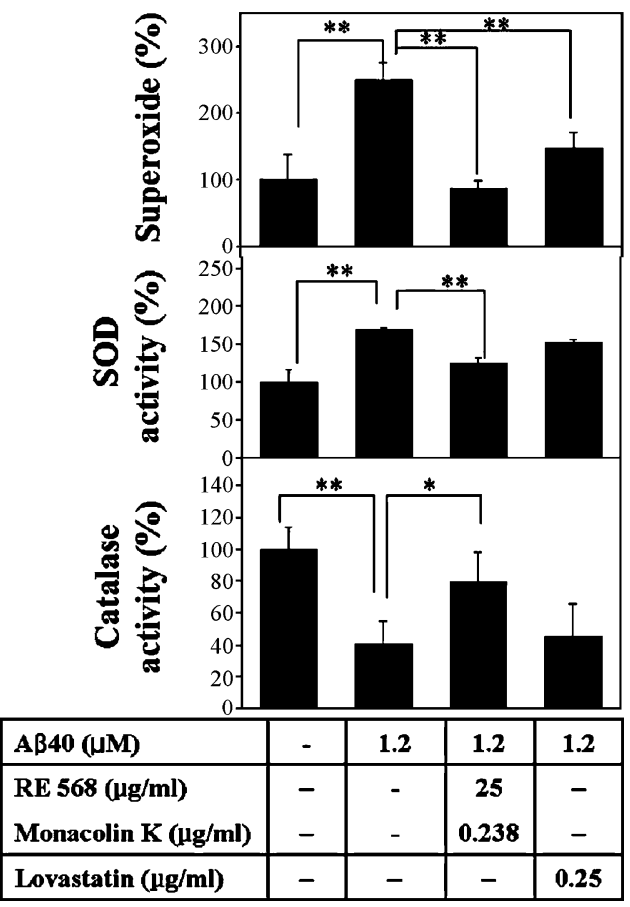

PC12 cell exposed in fibrils $\mathrm{A} \beta 40$, but the protective action cannot be performed by lovastatin treatment except inhibition of superoxide formation.

\section{Discussion}

According to the foregoing results, RE 568 treatment is certainly proven to attenuate $\mathrm{A} \beta 40$-induced cell death and the generation of iNOS, NO, ROS, and superoxide. Importantly, these facts all indicate that $A \beta$ neurotoxicity inhibition of RE 568 compares strongly with that of lovastatin. Figures 4 and 5 clearly indicate that RE 568 treatment performs better detoxification and anti-inflammation than lovastatin treatment. Therefore, monacolin K must not be a unique functional active ingredient because monacolin $\mathrm{K}$ concentration of various $\mathrm{RE}$ would not exhibit an absolute dose-dependent response in the repression of $\mathrm{A} \beta$ toxicity (Table 1). Many evidences attribute this fact to the synergism consisting of monacolin $\mathrm{K}$ and other metaboliteassociated antioxidant and anti-inflammatory agent. A strong antioxidation is shown in RE 568, which does not result from the existence of monacolin K (Fig. 6b). Many Monascus-related studies have proven the antioxidation via in vitro and in vivo experiment (Rhyu et al. 2000; Setnikar et al. 2005; Wu et al. 2003). Antioxidants such as vitamin C, flavanone, ergothioneine, and sesaminol glucosides are proven to protect $\mathrm{PC} 12$ cell against $\mathrm{A} \beta$-induced oxidative stress (Heo et al. 2004; Jang et al. 2004; Lee et al. 2005;
Yallampalli et al. 1998; Zhao 2005). The antioxidants of Monascus product are also proven to include dimerumic acid, tannin, phenol, unsaturated fatty acid, and other metabolites (Juzlova et al. 1996a, b; Rhyu et al. 2000). These complex antioxidants in RE $568(100 \mu \mathrm{g} / \mathrm{ml})$ perform synergistic antioxidation as robust as the $200 \mu \mathrm{M}$ vitamin $\mathrm{C}$ in this study (Fig. 6b). The synergism of monacolin $\mathrm{K}$ and other Monascus metabolites is not the first to be reported. In the atherosclerosis and hypertriglyceridemia clinical study, cholestin, a commercial Monascus product, is proven to exhibit a stronger effect on the treatment than lovastatin. The author also explained that the monacolin $\mathrm{K}$ content is only $5 \mathrm{mg}$, and therefore $5 \mathrm{mg}$ is the relevant comparison to 20 $40 \mathrm{mg}$ lovastatin. Monascus product always presented a more potent effect on lowering cholesterol than the equal level of lovastatin in clinical or animal model (Heber et al. 1999; Li et al. 2005; Wei et al. 2003). Heber et al. indicated that Monascus product contains sterols ( $\beta$-sitosterol, campesterol, stigmasterol, and sapogenin), isoflavones and isoflavone glycosides, and monounsaturated fatty acids in addition to a family of eight monacolins, and therefore the stronger cholesterol-lowering activity is unlikely to be due solely to a single species of monacolin but rather to result from a combination of actions of monacolins and other substances in Monascus product (Heber et al. 1999). According to these suppositions, Monascus product containing multifunctional complex and stronger cholesterollowering activity is certain to have an advantage over lovastatin drug. 
Cholesterol and isoprenoids biosynthesis have been proven to associate many signal transduction pathway and metabolic disease, so HMG-CoA reductase inhibitor, statins, has been used to remedy these diseases such as hyperlipidemia, atherosclerosis, heart disease, Alzheimer's disease, cancer, and osteoporosis (Davignon and Mabile 2001; Raja and Dreyfus 2004; Scott and Laake 2001). However, the therapy of statins often gave many researchers uneasiness because of the effect and overdose-induced side effect (Iskra et al. 2005). The clinical dosage of lovastatin is recommended to take with $20 \mathrm{mg}$ /day, but many clinical cases of AD take an overdose within 20-80 mg/day (Buxbaum et al. 1998; Hoglund et al. 2004). Overdose of statins had been proven to cause side effects such as myopathy, liver and renal function impairment, hypothyroidism, and diabetes mellitus (Iskra et al. 2005). Monascus product has been applied to the treatment of hyperlipidemia and atherosclerosis and demonstrated as a safe functional food with stronger cholesterol-lowering activity (Heber et al. 1999; Lee et al. 2006a; Wei et al. 2003).

Significant cholesterol-lowering effect was carried out by RE 568 including HMG-CoA reductase inhibitor monacolin $\mathrm{K}$ in Fig. 3, which is also involved in the blockade effect of isoprenoid biosynthetic pathway and small G-protein activation. The small G-protein is an essential factor in inflammatory signaling cascades, and thus a blockade of small G-protein lipid modification would functionally inhibit these pathways (Liao and Laufs 2005). The use of anti-inflammatory drug to repress $A \beta$ neurotoxicity has been reported by many studies. Epidemiological studies have shown that long-term use of nonsteroidal anti-inflammatory drugs reduces the risk of developing $\mathrm{AD}$ and delays its onset (Townsend and Pratico 2005). A $\beta$ neurotoxicity can be reversed more efficiently by the nonselective cyclooxygenase inhibitor indomethacin suggesting its role in modulating the signal transduction pathway involved in the mechanism of $A \beta$ neurotoxicity (Cahlin et al. 2005). Cannabidiol is shown to inhibit iNOS protein expression and NO production in beta-amyloidstimulated PC12 neurons through p38 mitogen-activated protein kinase and nuclear factor-kappa $\beta$ involvement (Esposito et al. 2006).

Monacolin $\mathrm{K}$ is certainly regarded as the functional active ingredient for attenuation of $\mathrm{A} \beta$-induced inflammation. In addition, RMR is a complex with multiple metabolites including monacolins and many functional compounds. The antioxidants of Monascus metabolites included dimerumic acid, tannin, phenol, monounsaturated fatty acid, and sterols. The anti-inflammatory agents have been proven to include monacolins, six azaphilones, monascin, ankaflavin, rubropunctatin, monascorburin, rubropunctamine, and monascorburamine, two furanoisophthalides, xanthomonasin $\mathrm{A}$ and xanthomonasin $\mathrm{B}$, and two amino acids, (+)-monascumic acid and (-)-monascumic acid (Akihisa et al. 2005; Aniya et al. 2000; Su et al. 2003). In this study, RE $568(100 \mu \mathrm{g} / \mathrm{ml})$ exhibited antioxidative ability including reducing power, DPPH radical scavenging activity, and conjugate diene inhibition as robust as $200 \mu \mathrm{M}$ vitamin $\mathrm{C}$.

In conclusion, the synergism of RE repressing $A \beta$ induced cytotoxin is shown in Fig. 7. Monacolin K existing in RE 568 suppresses $A \beta 40$-induced inflammatory re-
Fig. 7 A synergism of RE repressing $A \beta$-induced neurotoxicity

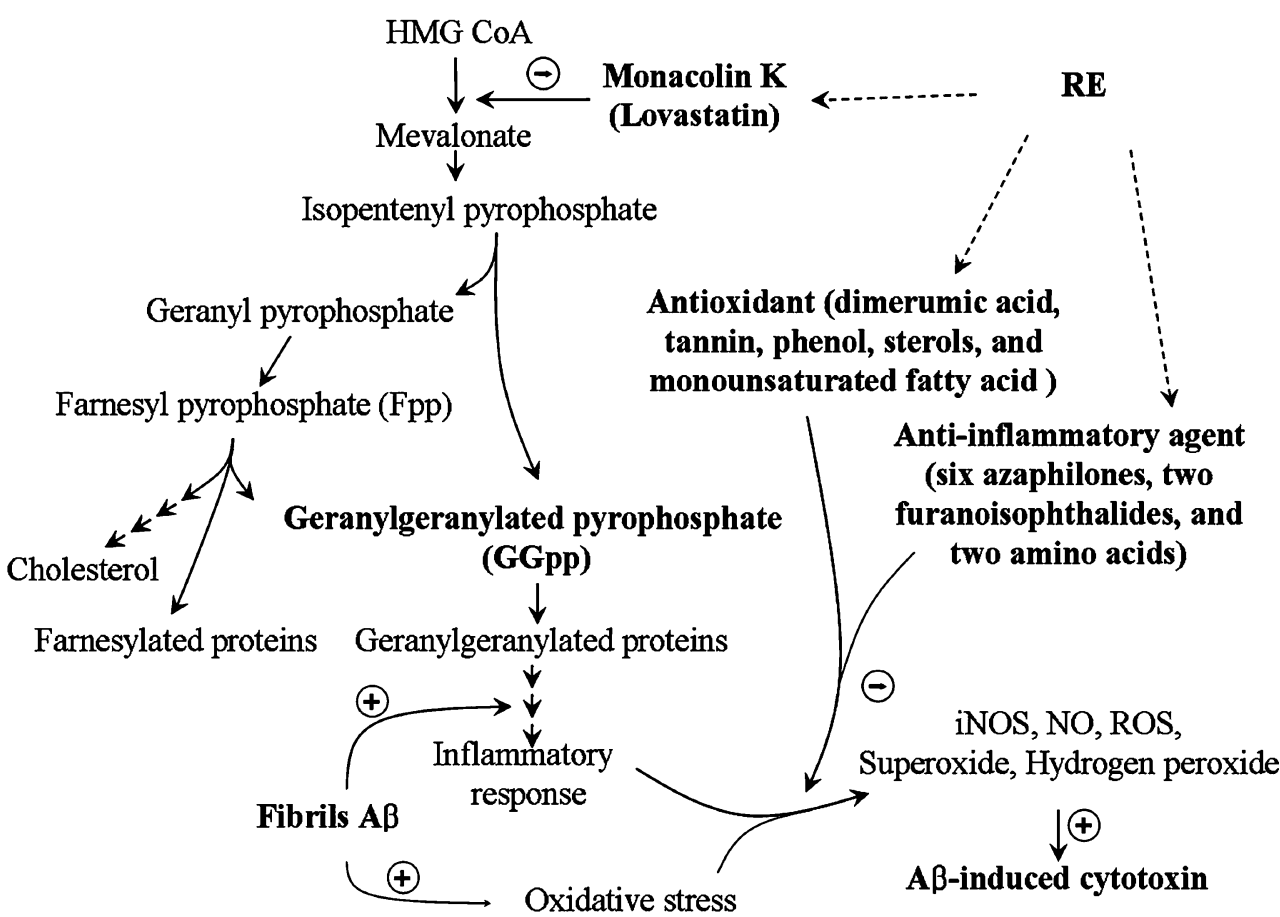


sponse and cell death via the blockade of isoprenoids GGpp generation and small G-protein activation. Besides monacolin $\mathrm{K}$, these antioxidants and anti-inflammatory agents perform the potent synergism to repress $A \beta$-induced inflammatory response and oxidative stress. Certainly, these synergistic effects performed more significant detoxification, anti-inflammation, and antioxidative stress ability against $A \beta 40$-induced cell damage than lovastatin treatment. Various functional metabolites presented in RMR probably perform better synergism on the therapy of $\mathrm{AD}$ pathogenesis than the single drug. RMR is usually regarded as a daily food and acts as a prophylactic supplement for lowering the risk of hyperlipidemia. Monascus-related researches never apply RMR to reduce the risk of $A D$ development such as $A \beta$-induced neurotoxicity. In addition, few of prophylactic food supplements with safeness and effectiveness are reported to reduce the risk of $\mathrm{AD}$ development. The present study provides a more complex view of the mechanism of action of RMR, and the potent synergistic mechanism would have an advantage over single lovastatin treatment and further cause RMR to be developed as potential and novel functional food for the prophylaxis of $\mathrm{AD}$ pathogenesis.

Acknowledgments This study was supported by a grant from the National Science Council, R.O.C. (NSC95-2313-B-002-019).

\section{References}

Akihisa T, Tokuda H, Yasukawa K, Ukiya M, Kiyota A, Sakamoto N, Suzuki T, Tanabe N, Nishino H (2005) Azaphilones, furanoisophthalides, and amino acids from the extracts of Monascus pilosus-fermented rice (red-mold rice) and their chemopreventive effects. J Agric Food Chem 53:562-565

Aniya Y, Yokomakura T, Yonamine M, Shimada K, Nagamine T, Shimabukuro M, Gibo H (1999) Screening of antioxidant action of various molds and protection of Monascus anka against experimentally induced liver injuries of rats. Gen Pharmacol 32:225-231

Aniya Y, Ohtani II, Higa T, Miyagi C, Gibo H, Shimabukuro M, Nakanishi H, Taira J (2000) Dimerumic acid as an antioxidant of the mold, Monascus anka. Free Radic Biol Med 28:999-1004

Beers RFJ, Sizer IW (1952) A spectrophotometric method for measuring the breakdown of hydrogen peroxide by catalase. J Biol Chem 195:133-140

Buxbaum JD, Thinakaran G, Koliatsos V, O, Callahan J, Slunt HH, Price DL, Sisodia SS (1998) Alzheimer amyloid protein precursor in the rat hippocampus: transport and processing through the perforant path. J Neurosci 18:9629-9637

Cahlin C, Gelin J, Andersson M, Lonnroth C, Lundholm K (2005) The effects of non-selective, preferential-selective and selective COX-inhibitors on the growth of experimental and human tumors in mice related to prostanoid receptors. Int $\mathrm{J}$ Oncol 27:913-923

Cordle A, Landreth G (2005) 3-Hydroxy-3-methylglutaryl-coenzyme A reductase inhibitors attenuate beta-amyloid-induced microglial inflammatory responses. J Neurosci 25:299-307
Cordle A, Koenigsknecht-Talboo J, Wilkinson B, Limpert A, Landreth G (2005) Mechanisms of statin-mediated inhibition of small Gprotein function. J Biol Chem 280:34202-34209

Davignon J, Mabile L (2001) Mechanisms of action of statins and their pleiotropic effects. Ann Endocrinol (Paris) 62:101-112

Endo A (1979) Monacolin K, a new hypocholesterolemic agent produced by a Monascus species. J Antibiot (Tokyo) 32:852-854

Esposito G, De Filippis D, Maiuri MC, De Stefano D, Carnuccio R, Iuvone $\mathrm{T}$ (2006) Cannabidiol inhibits inducible nitric oxide synthase protein expression and nitric oxide production in betaamyloid stimulated PC12 neurons through p38 MAP kinase and NF-kappaB involvement. Neurosci Lett 399:91-95

Gao X, Tang XC (2006) Huperzine A attenuates mitochondrial dysfunction in beta-amyloid-treated $\mathrm{PC} 12$ cells by reducing oxygen free radicals accumulation and improving mitochondrial energy metabolism. J Neurosci Res 83:1048-1057

Green LC, Wagner DA, Glogowski J, Skipper PL, Wishnok JS, Tannenbaum SR (1982) Analysis of nitrate, nitrite, and [15N] nitrate in biological fluids. Anal Biochem 126:131-138

Heber D, Yip I, Ashley JM, Elashoff DA, Elashoff RM, Go VL (1999) Cholesterol-lowering effects of a proprietary Chinese red-yeastrice dietary supplement. Am J Clin Nutr 69:231-236

Heo HJ, Kim DO, Choi SJ, Shin DH, Lee CY (2004) Potent inhibitory effect of flavonoids in Scutellaria baicalensis on amyloid beta protein-induced neurotoxicity. J Agric Food Chem 52:4128-4132

Hoglund K, Wiklund O, Vanderstichele H, Eikenberg O, Vanmechelen E, Blennow K (2004) Plasma levels of beta-amyloid(1-40), betaamyloid(1-42), and total beta-amyloid remain unaffected in adult patients with hypercholesterolemia after treatment with statins. Arch Neurol 61:333-337

Iskra B, Zivko M, Kes P (2005) Rhabdomyolysis as a side effect of simvastatin treatment. Acta Med Croatica 59:325-328

Iuvone T, De Filippis D, Esposito G, D, Amico A, Izzo AA (2006) The spice sage and its active ingredient rosmarinic acid protect PC12 cells from amyloid-beta peptide-induced neurotoxicity. J Pharmacol Exp Ther 317:1143-1149

Jang JH, Aruoma OI, Jen LS, Chung HY, Surh YJ (2004) Ergothioneine rescues PC12 cells from beta-amyloid-induced apoptotic death. Free Radic Biol Med 36:288-299

Juzlova P, Martinkova L, Kren V (1996a) Secondary metabolites of the fungus Monascus: a review. J Ind Microbiol 16:163-170

Juzlova P, Rezanka T, Martinkova L, Kren V (1996b) Long-chain fatty acids from Monascus purpureus. Phytochemistry 43: $151-153$

Lee SY, Lee JW, Lee H, Yoo HS, Yun YP, Oh KW, Ha TY, Hong JT (2005) Inhibitory effect of green tea extract on beta-amyloidinduced PC12 cell death by inhibition of the activation of NFkappaB and ERK/p38 MAP kinase pathway through antioxidant mechanisms. Brain Res Mol Brain Res 140:45-54

Lee CL, Tsai TY, Wang JJ, Pan TM (2006a) In vivo hypolipidemic effects and safety of low dosage Monascus powder in a hamster model of hyperlipidemia. Appl Microbiol Biotechnol 70: $533-540$

Lee CL, Wang JJ, Kuo SL, Pan TM (2006b) Monascus fermentation of dioscorea for increasing the production of cholesterol-lowering agent-monacolin $\mathrm{K}$ and anti-inflammation agent-monascin. Appl Microbiol Biotechnol 72:1254-1262

Lee CL, Wang JJ, Pan TM (2006c) Synchronous analysis method for detection of citrinin and the lactone and acid forms of monacolin $\mathrm{K}$ in red mold rice. J AOAC Int 89:669-677

Lee HG, Zhu X, Nunomura A, Perry G, Smith MA (2006d) Amyloid beta: the alternate hypothesis. Curr Alzheimer Res 3:75-80

Lee CL, Hung HK, Wang JJ, Pan TM (2007) Red mold dioscorea has greater hypolipidemic and antiatherosclerotic effect than traditional red mold rice and unfermented dioscorea in hamsters. J Agric Food Chem 55:7162-7169 
Li Z, Seeram NP, Lee R, Thames G, Minutti C, Wang HJ, Heber D (2005) Plasma clearance of lovastatin versus Chinese red yeast rice in healthy volunteers. J Altern Complement Med 11:1031-1038

Liao JK, Laufs U (2005) Pleiotropic effects of statins. Annu Rev Pharmacol Toxicol 45:89-118

Lingnert H, Vallentin K, Eriksson CE (1979) Measurement of antioxidative in model system. J Food Process Preserv 3:87-103

Oyaizu M (1986) Antioxidative activity of browning products of glucosamine fractionated by organic solvent and thin-layer chromatography. Nippon Shokuhin Kogyo Gakkaishi 35:771-775

Pollack SJ, Sadler II, Hawtin SR, Tailor VJ, Shearman MS (1995) Sulfated glycosaminoglycans and dyes attenuate the neurotoxic effects of beta-amyloid in rat PC12 cells. Neurosci Lett 184:113-116

Raja SG, Dreyfus GD (2004) Statins: much more than just a lipidlowering therapy. Indian Heart J 56:204-209

Rhyu MR, Kim DK, Kim HY, Kim BK (2000) Nitric oxide-mediated endothelium-dependent relaxation of rat thoracic aorta induced by aqueous extract of red rice fermented with Monascus ruber. J Ethnopharmacol 70:29-34

Rockwood K, Kirkland S, Hogan DB, MacKnight C, Merry H, Verreault R, Wolfson C, McDowell I (2002) Use of lipidlowering agents, indication bias, and the risk of dementia in community-dwelling elderly people. Arch Neurol 59:223-227

Sastre M, Klockgether T, Heneka MT (2006) Contribution of inflammatory processes to Alzheimer's disease: molecular mechanisms. Int J Dev Neurosci 24:167-176

Scott HD, Laake K (2001) Statins for the prevention of Alzheimer's disease. Cochrane Database Syst Rev 2001(3):CD003160
Setnikar I, Senin P, Rovati LC (2005) Antiatherosclerotic efficacy of policosanol, red yeast rice extract and astaxanthin in the rabbit. Arzneimittelforschung 55:312-317

Su YC, Wang JJ, Lin TT, Pan TM (2003) Production of the secondary metabolites gamma-aminobutyric acid and monacolin $\mathrm{K}$ by Monascus. J Ind Microbiol Biotechnol 30:41-46

Townsend KP, Pratico D (2005) Novel therapeutic opportunities for Alzheimer's disease: focus on nonsteroidal anti-inflammatory drugs. Faseb J 19:1592-1601

Wei W, Li C, Wang Y, Su H, Zhu J, Kritchevsky D (2003) Hypolipidemic and anti-atherogenic effects of long-term Cholestin (Monascus purpureus-fermented rice, red yeast rice) in cholesterol fed rabbits. J Nutr Biochem 14:314-318

Wolozin B, Kellman W, Ruosseau P, Celesia GG, Siegel G (2000) Decreased prevalence of Alzheimer disease associated with 3hydroxy-3-methyglutaryl coenzyme A reductase inhibitors. Arch Neurol 57:1439-1443

Wu LC, Chen YC, Ho JA, Yang CS (2003) Inhibitory effect of red koji extracts on mushroom tyrosinase. J Agric Food Chem 51:4240-4246

Xiao XQ, Wang R, Tang XC (2000) Huperzine A and tacrine attenuate beta-amyloid peptide-induced oxidative injury. J Neurosci Res 61:564-569

Yallampalli S, Micci MA, Taglialatela G (1998) Ascorbic acid prevents beta-amyloid-induced intracellular calcium increase and cell death in PC12 cells. Neurosci Lett 251:105-108

Zhao B (2005) Natural antioxidants for neurodegenerative diseases. Mol Neurobiol 31:283-293 